\title{
The Effect of Servant Leadership, Job Satisfaction and Quality of Work Life on Organizational Citizenship Behavior
}

\author{
Wachyu Hari HAJI ${ }^{*}$, Christina Catur WIDAYATI², Harries MADIISTRIYATNO ${ }^{3}$, \\ Muhammad Royan FEBRIANTO
}

\begin{abstract}
${ }^{1}$ Lecturer/Dr/Master of Management Study Program, University Mercu Buana, Jakarta, Indonesia, Jl. Meruya Selatan Kembangan Jakarta Barat 11650, Email: wahyuhari@mercubuana.ac.id

${ }^{2}$ Lecturer/Dr/Faculty of Economics and Business, University Mercubuana, Jakarta, Indonesia, Jl. Meruya Selatan Kembangan Jakarta Barat 11650, Email: catur.widayati@mercubuana.ac.id/christinewijaya73@yahoo.co.id

${ }^{3}$ Lecturer/Master of Management Study Program STIMA IMMI, Jl. Raya Tj. Barat Jl. Raya Pasar Minggu No.11, RT.11/RW.8, Pejaten Tim., Kec. Ps. Minggu, Kota Jakarta Selatan, Daerah Khusus Ibukota Jakarta 12520,

Email: harries.madi@gmail.com
\end{abstract}

${ }^{4}$ Faculty of Economics and Business, University Mercubuana, Jakarta, Indonesia, Jl. Meruya Selatan Kembangan Jakarta Barat 11650, Email: Royan671@gmail.com

* Corresponding Author

\section{Received: 08.07.2021 Accepted: 07.09.2021 Published: 25.10.2021 DOI: $\underline{10.47750 / Q A S / 22.184 .26}$}

\begin{abstract}
This study aims to build a model by linking the role of servant leadership, job satisfaction, and quality of work life to organizational citizenship behavior (OCB) in employees. In this study used a research design that is the type of causal research. The problem studied is the influence of servant leadership, job satisfaction and quality of work life on organizational citizenship behavior (OCB). The population in this study are employees of PT. Triple One Global with a total of 80 people. The sample selection method used in this study is the saturated sample technique method, ie all the population is sampled. In this study, the authors used data collection techniques with library research and field research by distributing questionnaires. The analytical technique used is the Structural Equation Model (SEM) with the Smart-PLS 3.3.2 analysis tool. The results showed that: 1) servant leadership had a positive and significant effect on organizational citizenship behavior (OCB), 2) job satisfaction had a positive and significant effect on organizational citizenship behavior (OCB), and 3) quality of work life had a positive and significant effect on organizational citizenship behavior (OCB). Suggestions from this research are, leaders should be able to provide a sense of security and calm in employees doing their work, and also increase employee satisfaction, and provide benefits that are in accordance with the performance that has been produced by employees so that employees can foster a sense of concern for others.
\end{abstract}

Keywords: Servent Leadership, Job Satisfaction, Quality of Work Life, Organizational Citizenship Behavior (OCB)

\section{Introduction}

Human resources $(\mathrm{HR})$ is one of the important supports for running activities within the organization to participate in the organization's strategic plan so that human resources are the most important assets in human life today. Mangkunegara (2015) states that personnel management and human resources are very important for companies in managing, managing, and utilizing employees to function productively to achieve company goals. Without realizing it, to produce good competence, HR management must be considered because it is an important key to success for the company.

Human resources are considered the most valuable and scarce things. Its implementation states that organizations need employees who can behave well, such as helping other individuals in the team, volunteering for extra work, avoiding unnecessary conflicts, respecting regulations, and being willing to tolerate work-related losses and disturbances. To regulate effectiveness means achieving goals according to planning and efficiency, meaning that the existing tasks are carried out correctly, organized, and following the targets set by Montolalu (2016).

Mira and Margaretha (2012) reminded the importance of the human aspect for an organization, so a leader's role is no less important. It is hoped that a leader's decisions and policies will affect not only the success of the organization but also the behavior of all its employees. The leader's ability to influence others will motivate employees to do something to achieve the desired goals.

Leadership is one of the external factors in realizing Organizational Citizenship Behavior (OCB) in employees. Companies need strong leadership and management in terms of optimal effectiveness to create a vision for the future and inspire the organization's members to achieve the vision that has been made. It requires formulating detailed plans at the manager level, creating an efficient organizational structure, and supervising daily activities (Robbin \& Judge, 2015). The leadership style that each company leader has will be different, one of which is leadership that can provide the best service to 
build trust in employees or what is commonly known as servant leadership. Poli (2011) states that servant leadership is a process of a reciprocal relationship between the leader and those who have been led, wherein the process of the leader appears first as the party who needs the lead, which ultimately causes him to be recognized and accepted as a leader.

In the observations (preliminary surveys) conducted by researchers, there are problems related to some employees who do not pay attention to completing tasks promptly, using cellphones during working hours that are not related to work, and only doing their tasks and responsibilities, so that they feel empathy for helping others-colleagues who have less workload. The results of the initial survey conducted by researchers show that the flow behavior of the Organizational Citizenship Behavior (OCB) is caused by a crisis of trust in leaders and related workloads. It can indicate employees' lack of understanding of Organizational Citizenship Behavior (OCB) and lack of support from the leader to work optimally. If this is done continuously, it will cause work problems and will not create good organizational behavior, and job satisfaction will not be achieved.

This phenomenon shows that the highest level of employee absenteeism is illness (15.7\%), then the second is alpha with a figure of $11.4 \%$, and finally due to permission with a figure of $10.1 \%$. Based on these data, something is interesting, absence without reason (alpha) in the second position. It is supported by the results of an interview with Mr. Isak Rabin as the HR Manager that this company has a problem with the level of Organizational Citizenship Behavior (OCB), which can be shown from current working habits. Therefore the level of employee discipline impacts the responsibility and commitment they have to the organization. If this continues, the company's productivity level is low and creates problems such as not achieving organizational goals. As a result, companies will find it difficult to cultivate and improve Organizational Citizenship Behavior (OCB) in employees. It can be seen from one of the dimensions of OCB, namely conscientiousness, which describes an orderly and orderly person, full of self-control, organized, ambitious, focused on achievement, and selfdiscipline.

\begin{tabular}{|l|l|l|l|}
\hline Year & Target & Achievement & Percentage \\
\hline 2017 & $2,2 \mathrm{M}$ & $700 \mathrm{Jt}$ & $30 \%$ \\
\hline 2018 & $5,5 \mathrm{M}$ & $4 \mathrm{M}$ & $80 \%$ \\
\hline 2019 & $13 \mathrm{M}$ & $5.6 \mathrm{M}$ & $41 \%$ \\
\hline
\end{tabular}

Table 1: Target data of PT. Triple One Global

Source: Data from the Recruitment business unit of PT. Triple One Global (Data processed in 2019).

In addition to the high absence of employees, PT Triple One Global has a relatively high company target, but employees have difficulty meeting company targets in reality. Not achieving the company's target is probably due to a decline in employees due to the OCB factor. It is due to the employees' inadequate performance or the results of the work of the employees, which results in not achieving company targets, which in turn has an impact on not achieving predetermined company revenues. One of the factors that resulted in not achieving targets was low awareness of their work responsibilities.

Based on these problems, researchers conducted a presurvey of 20 employees of PT. Triple One Global is to determine the factors that are considered to lead to Organizational Citizenship Behavior (OCB) with the following results:

\begin{tabular}{|c|c|c|c|}
\hline No & Statement & Yes & No \\
\hline \multicolumn{4}{|c|}{ Organizational Citizenship Behavior (OCB) } \\
\hline 1. & $\begin{array}{l}\text { I am willing to put the extra effort in addition to predetermined work to } \\
\text { help succeed. }\end{array}$ & 9 & 11 \\
\hline 2. & I help colleagues to work more productively & 7 & 13 \\
\hline 3. & I help colleagues who have a lot of work. & 9 & 11 \\
\hline \multicolumn{4}{|c|}{ Job satisfaction } \\
\hline 4. & I feel a sense of satisfaction in working at this company. & 9 & 11 \\
\hline 5. & This job is perfect for me, so I feel very happy here. & 5 & 15 \\
\hline 6. & I am really satisfied with my work, because I am making progress here. & 9 & 11 \\
\hline \multicolumn{4}{|c|}{ Servant Leadership } \\
\hline 7. & $\begin{array}{l}\text { I pay attention to everything that provides information about the } \\
\text { company. }\end{array}$ & 5 & 15 \\
\hline 8. & When someone criticizes my boss, it feels like slurs at me too. & 4 & 16 \\
\hline 9. & $\begin{array}{l}\text { When I talk about my boss, I usually use the term "we", rather than "him/ } \\
\text { them." }\end{array}$ & 7 & 13 \\
\hline 10. & $\begin{array}{l}\text { I feel that my supervisor has an "ownership" spirit (assumes the } \\
\text { existence of a subordinate). }\end{array}$ & 9 & 11 \\
\hline \multicolumn{4}{|c|}{ Quality of Work Life } \\
\hline 11. & $\begin{array}{l}\text { I feel satisfied regarding the freedom of expression (opportunity to } \\
\text { express opinions) that exists in the company. }\end{array}$ & 5 & 15 \\
\hline 12. & I work according to the working hours set by the company. & 9 & 11 \\
\hline
\end{tabular}




\begin{tabular}{|l|l|l|l|}
\hline 13. & I work according to the working hours set by the company. & 7 & 13 \\
\hline 14. & I am satisfied with the salary given. & 7 & 13 \\
\hline Empathy & 11 & 9 \\
\hline 15. & I love and care about my colleagues. & 13 & 7 \\
\hline 16. & $\begin{array}{l}\text { I can tell when other people are covering up their true emotions or } \\
\text { feelings. }\end{array}$ & 12 & 8 \\
\hline 17. & I am more concerned with the interests of others than my interests. & 15 & 5 \\
\hline 18. & I am interested in knowing the problem of a friend in detail. & 10 & 10 \\
\hline 19. & I am interested in knowing the problem of a friend in detail. & 10 \\
\hline
\end{tabular}

Table 2: Pre-Survey Questionnaire

From the pre-survey table, the result shows that there are indications of problems due to the lack of Organizational Citizenship Behavior (OCB), behavior among employees at PT Triple One Global, which is found in pre-survey data number 1 , 2 , and number 3. Employees show that most of them are dissatisfied at work. It can be seen from pre-survey data numbers 4, 5, and 6. The servant leadership style, which creates a lack of trust in the leadership and tends to show less than optimal work results, can be seen from the pre-survey data $7,8,9$, and 10 . The lack of quality of work-life and responsibility from within employees to achieve the vision goals and the mission to the company can be seen from the pre-survey data numbers $11,12,13$, and 14 .

From two sides of interest: employees as individuals and companies, in this case for the formation of the process, is complementary where employees need about the benefits from the company and vice versa the company requires employees to excel, it is very important to realize that employee work behavior must be able to run well. and controlled according to company operational standards, so that individual behavior of employees can be directed according to company expectations to achieve predetermined goals.

Organizational Citizenship Behavior (OCB) in an employee company is one of the most important aspects. If there are no employees, the company will not run well. However, every employee has a job description and duties for each employee to manage the balance of time balance, the balance of involvement, and balance of satisfaction. Ideally, someone has an OCB in him. He shows voluntary behavior outside the predetermined job descriptions to improve the progress of organizational performance. Employees must also have responsibility for all other employee duties, or it is also called Organizational Citizenship Behavior (OCB). If an employee does not have Organizational Citizenship Behavior (OCB), the job and company goals will not be achieved. It is what causes dissatisfaction and discomfort at work. Many studies raise issues such as the above discussion, including research results from Mira and Margareta (2012), Sedarmayanti and Kuswanto (2015), Al-amri (2016), Setiawan (2019). shows that servant leadership has a positive and significant effect on Organizational Citizenship Behavior (OCB).

Another factor that affects Organizational Citizenship Behavior (OCB) is job satisfaction. Job satisfaction is a factor that has a significant effect on Organizational Citizenship Behavior (OCB). It is reinforced by research conducted by Barlian (2016), Rohayati (2014), Oktavia and Laily (2017), which shows that there is a positive and significant influence between job satisfaction. against Organizational Citizenship Behavior (OCB). Research conducted by Rohayati (2014) also states that job satisfaction has a positive effect. Job satisfaction is considered a result of the employee's experience with his values, like what is desired and expected This view can be simplified that job satisfaction is an attitude of the individual and feedback on his work. The results of further research, according to Uttunggadewi and Indrawati (2019), Ardilla, Hulmansyah, Huda (2018), Kashani (2012), show that Quality of Work-Life has a positive and significant effect on Organizational Citizenship Behavior (OCB). In this study, the author will conduct a different study from previous studies, where the variables to be discussed include the effect of servant leadership, job satisfaction, Quality of Work Life on Organizational Citizenship Behavior (OCB), and this research was conducted at PT Triple One Global.

The problems in this study are (1) Does Servant Leadership's influence affects the Organizational Citizenship Behavior (OCB) of PT. Triple One Global? (2) Does the influence of Job Satisfaction affect the Organizational Citizenship Behavior (OCB) of PT. Triple One Global ?; (3) Does Quality of Work-Life affect the Organizational Citizenship Behavior (OCB) of PT. Triple One Global?

While the research objectives in this study were: (1) To determine and analyze the effect of Servant Leadership on Organizational Citizenship Behavior (OCB); (2) To determine and analyze the effect of Job Satisfaction on Organizational Citizenship Behavior (OCB); (3) To determine and analyze the influence of Quality of Work Life on Organizational Citizenship Behavior (OCB).

\section{Theoritical Review}

\subsection{Organizational Citizenship Behavior (OCB)}

Organizational Citizenship Behavior (OCB) is an individual contribution that exceeds the workplace's role demands and will be rewarded based on individual performance results. Organizational Citizenship Behavior (OCB) involves several behaviors, including helping others, volunteering for extra tasks, obeying rules and procedures in the workplace. These behaviors illustrate the "added value of employees" Putrana (2016).According to Titisari (2014), Organizational Citizenship Behavior (OCB) is an individual contribution that exceeds the demands of a role in the workplace. Organizational Citizenship Behavior (OCB) is the behavior of company employees to increase the effectiveness of company performance without neglecting individual employee productivity goals. Herminingsih and Merdeka (2021), organizational citizenship behavior (OCB) is part of the science of organizational behavior, OCB which is usually not seen or taken in to account. There are two approaches to the concept of organizational citizenship behavior, namely organizational citizenship behavior, which is an extra role performance that is separate from inrole performance of performance that matches the job description. 


\subsection{Servant Leadership}

Servant Leadership is the attitude of leaders who serve to go beyond their interests and emphasize opportunities to help their followers grow and develop Robbin \& Judge (2015). According to Yulk (2015), Servant leadership in the workplace is about building other people to build common goals by facilitating the development, empowerment, and collective work of individuals consistent with the long-term health and well-being of followers.

\subsection{Job satisfaction}

According to the Main Dictionary of Bahasa Indonesia, satisfaction is the feeling of being happy, happy, and relieved because the day's desire has been fulfilled. Meanwhile, job satisfaction is defined as a pleasant psychological state felt by workers in a work environment because a need is fulfilled adequately. In other words, job satisfaction is someone's active response to a job. According to Hasibuan (2014), job satisfaction is an emotional attitude that is fun and loves their job. Job satisfaction employees must be created and possible so that work morale, dedication, love, and employee discipline increase. This attitude is reflected by work morale, discipline, and work performance.

George \& Jones (2012) states that job satisfaction is a set of feelings and beliefs that an individual has about his current job. Sutrisno (2014) states that job satisfaction is a pleasant or unpleasant emotional state for employees to view their work. Meanwhile, according to Robbins \& Judge (2015), job satisfaction is a positive feeling for a job that results from the individual evaluation process of the work's characteristics being carried out. In this case, Robbins \& Judge (2015) emphasize the notion of job satisfaction for the assessment of individuals on work such as job challenges, support from colleagues, commensurate salaries, and others.

\subsection{Quality of Work Life}

Parvar et al., (2013) stated that Work-Life's quality is an effective program for improving working conditions and organizational effectiveness. In this case, the quality of WorkLife can motivate employees to work very well in the work environment. Also, employee satisfaction will be a priority for the company to be maintained and carried out. Quality of Work Life is one way to make employees loyal to the company. In its application, it will also be able to make employees improve the quality of their work. If employees have obtained Quality of Work Life, they will feel a positive relationship with the company that makes them satisfied and motivated at work.

\section{The Effect of Servant Leadership on Organizational Citizenship Behavior (OCB)}

Servant Leadership can trigger employees to generate voluntary behavior in helping colleagues or what can be called Organizational Citizenship Behavior (OCB). A leader will become a role model for his employees, so if the leader can carry out his serving leadership, the employees will not hesitate to have Organizational Citizenship Behavior (OCB) attitudes or behaviors.

Research conducted by Mira and Margareta (2012) found that servant leadership positively and significantly affects Organizational Citizenship Behavior (OCB). Research conducted by Sedarmayanti and Kuswanto (2015) found that servant leadership positively and significantly affects Organizational Citizenship Behavior (OCB). Research conducted by Al-amri (2016) found that servant leadership positively and significantly affects Organizational Citizenship
Behavior (OCB). Influential research conducted by Harwiki (2015) found that servant leadership positively and significantly affects Organizational Citizenship Behavior (OCB). Then research conducted by Newman (2017) found that servant leadership has a significant effect on Organizational Citizenship Behavior (OCB).Based on the results of the statements from several studies above, it can be concluded that servant leadership has a positive and significant effect on Organizational Citizenship Behavior (OCB), so the following hypothesis can be formulated:

H1: Servant Leadership has a significant effect on Organizational Citizenship Behavior (OCB).

\section{The Effect of Job Satisfaction on Organizational Citizenship Behavior (OCB)}

Job satisfaction shows a match between someone's expectations that arise with the rewards provided by the job. Research conducted by Ai Rohayati (2014) states that there is a positive and significant influence between job satisfaction and Organizational Citizenship Behavior (OCB). The same statement is also found in Oktavia and Laily's (2017) research that job satisfaction positively and significantly affects Organizational Citizenship Behavior (OCB). However, research conducted by Barlian (2016) states that job satisfaction has a positive and significant effect on Organizational Citizenship Behavior (OCB).Based on the results of the statements from several studies above, it can be concluded that job satisfaction has a positive and significant effect on Organizational Citizenship Behavior (OCB), so the following hypothesis can be formulated:

H2: Job satisfaction affects Organizational Citizenship Behavior (OCB)

\section{Effect of Quality of Work Life on Organizational Citizenship Behavior (OCB)}

Quality of Work Life is the feasibility of working conditions provided by the company so that employees can work well, improving overall organizational performance. At the same time, Organizational Citizenship Behavior (OCB) is a prosocial behavior that arises from decent working conditions, which attracts employees to actualize fully. Influential research conducted by Ardilla, Hulmansyah, Huda (2018) found that Quality of Work-Life has a positive and significant effect on Organizational Citizenship Behavior (OCB). Influential research conducted by Pio, Riane John, and Florence Daisy Jetty Lengkong (2020) found that Quality of Work-Life has a positive and significant effect on Organizational Citizenship Behavior (OCB). The same statement is also found in research conducted by Kashani (2012), which found that Quality of Work-Life has a positive and significant effect on Organizational Citizenship Behavior (OCB). However, research conducted by Uttunggadewi and Indrawati (2019) states that Quality of Work-Life has a positive and significant influence on Organizational Citizenship Behavior.Based on the results of the statements from several studies above, it can be concluded that Quality of Work-Life has a positive and significant effect on Organizational Citizenship Behavior (OCB), so the following hypothesis can be formulated:

H3: Quality of Work-life affects Organizational Citizenship Behavior (OCB).

\section{Method}

\subsection{Time and Place of Research}

What is done before conducting the research, the author 


\section{GENERAL MANAGEMENT}

identifies problems that occur in the place to be used as the research location and at the same time formulates problems, collects theoretical bases that strengthen the basis for variables, dimensions, and indicators, and compiles methods for data collection and instruments, thus determining statistical testing techniques used. This process requires research time from September 2019 to September 2020. To obtain this research data, researchers researched PT Triple One Global, Jakarta, located at Jalan Aren No.29 Jati Pulo, Palmerah, West Jakarta.

\subsection{Research Design}

The research design used in causal research is a causal relationship of a problem. So there are independent variables (variables that affect) and dependent (variables that are affected). This study consisted of three independent variables: Servant Leadership, Job Satisfaction, Quality of Work Life, and one dependent variable, namely Organizational Citizenship Behavior (OCB). This study aims to determine the effect of Servant Leadership, Job Satisfaction, and Quality of Work Life on Organizational Citizenship Behavior (OCB) in employees of PT Triple One Global.

In this study, the measurement scale used by researchers is the Likert scale. According to Sugiyono (2013), the Likert scale is used to measure people's attitudes, opinions, and perceptions about social phenomena. With the Likert scale, the variables to be measured are translated into variable indicators, and then these indicators are used as a starting point for compiling instrument items which can be in the form of statements or questions.

\subsection{Population and Research Sample}

According to Sugiyono (2013), the population is a generalization area consisting of objects or subjects with certain qualities and characteristics that researchers determine to study and then draw conclusions. Based on PT Triple One Global West Jakarta's information, the population in this study were 100 employees who worked at PT Triple One Global.

Sugiyono (2013) explains that the sample is part of the number and characteristics of the population. The research sample is a portion of the population taken as a data source and can represent the entire population. The saturated sample is a sampling technique if all population members are used as samples taken from that population must be truly representative. Convenience Sampling is a sampling technique based on chance, the population members that the researcher meets at the research location, and willing to be the respondents to be sampled. If the sample is not representative, it will not be easy to make conclusions from what is being studied. The saturated sample is also often interpreted as the maximum sample, plus any amount will not change the representativeness. This study uses a sample of 80 employees from a total population of 100 employees, of which the number of samples not taken is 20 employees consisting of $15 \mathrm{HL}$ (freelance daily) Operators, 3 data entries, one project manager, one business analyst.

\section{Result And Discussion}

\subsection{Hypothesis Testing Result}

\begin{tabular}{|l|l|l|l|l|l|}
\hline & $\begin{array}{l}\text { Original } \\
\text { Sample }\end{array}$ & $\begin{array}{l}\text { Standard } \\
\text { Deviation }\end{array}$ & $\begin{array}{l}\text { T- } \\
\text { Statistics }\end{array}$ & $\begin{array}{l}\text { P- } \\
\text { Values }\end{array}$ & Explanation \\
\hline $\begin{array}{l}\text { Servant Leadership } \rightarrow \\
\text { Organizational Citizenship } \\
\text { Behavior }\end{array}$ & 0.565 & 0.080 & 7.062 & 0.000 & $\begin{array}{l}\text { Positive- } \\
\text { Significant }\end{array}$ \\
\hline $\begin{array}{l}\text { Job satisfaction } \rightarrow \\
\text { Organizational Citizenship } \\
\text { Behavior }\end{array}$ & 0.775 & 0.083 & 9.329 & 0.000 & $\begin{array}{l}\text { Positive } \\
\text { Significant }\end{array}$ \\
\hline $\begin{array}{l}\text { Quality Of Work Life } \rightarrow \\
\text { Organizational Citizenship } \\
\text { Behavior }\end{array}$ & 0.401 & 0.084 & 4.783 & 0.000 & $\begin{array}{l}\text { Positive } \\
\text { Significant }\end{array}$ \\
\hline
\end{tabular}

Table 3. Hypothesis Test (Inner Model) Source: PLS Output, 2020 


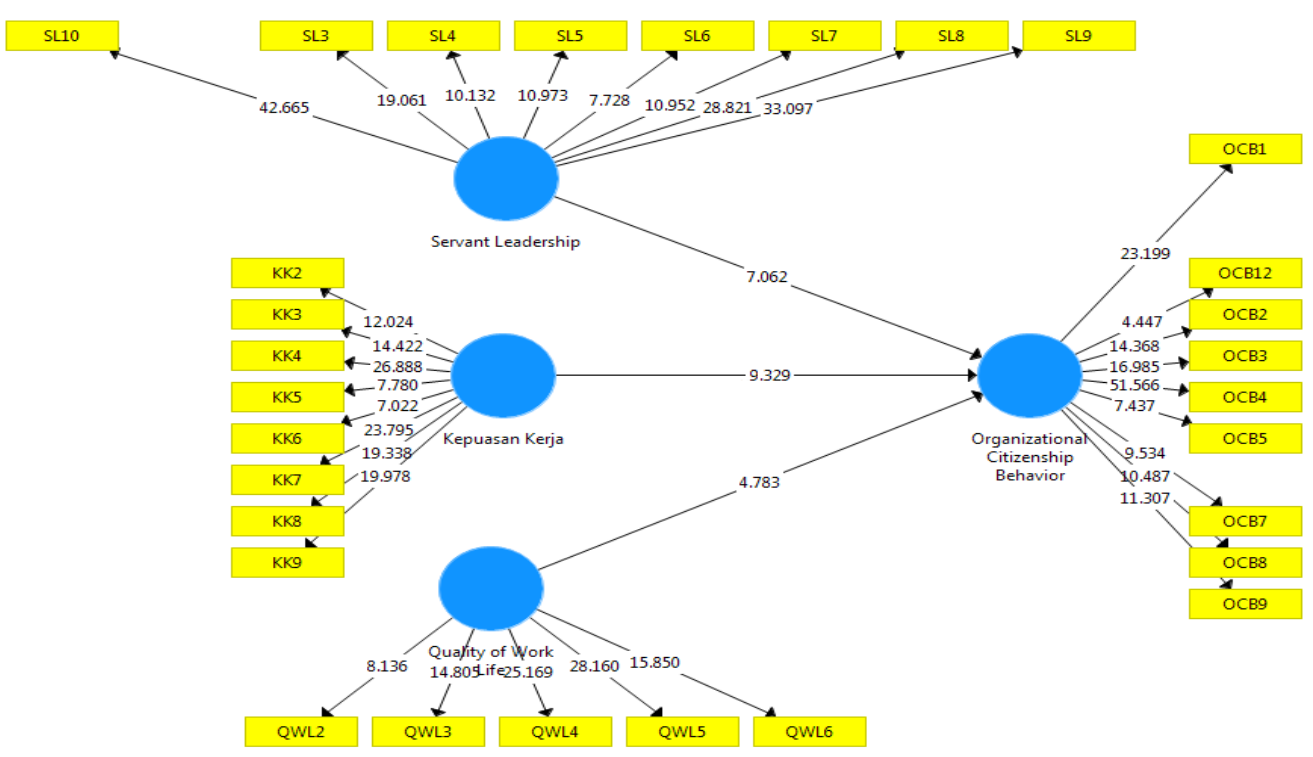

Figure 1: Boostrapping Test Results Source: PLS Output, 2020

\subsection{Effect of Servant Leadership on Organizational Citizenship Behavior}

Based on the hypothesis testing in this study, the T-statistic value was 7,062 , the original sample value was 0.565 , and the $\mathrm{P}$-value was 0.000 . The T-statistic value is greater than the $T$ table value of 1.96 , the original sample value shows a positive value, and the $P$-value is less than 0.05 . These results indicate that servant leadership has a positive and significant effect on organizational citizenship behavior.

Servant leadership can trigger employees to raise voluntary behavior in helping colleagues or what can be called organizational citizenship behavior (OCB). A leader is someone whose actions and behavior become an example for his followers. The employees will follow the decisions made by the leader. Apart from being smart and wise, a leader who is needed is a leader who can serve employees. Leaders' relationships with employees that are built with serving behavior will foster emotional closeness. It encourages employees to improve performance. So it can be concluded that the stronger the servant leadership, the organizational citizenship behavior in PT. Triple One Global will experience an increase. The dimensions of emotional healing and organizational stewardship in the servant leadership variable at PT. Triple One Global has a very high category index score. So that the presence of servant leadership at PT. Triple One Global provides meaning to involve and develop employees to continue to grow in the company.

This study is supported by Sedarmayanti and Kuswanto (2015), which found that servant leadership positively and significantly affects organizational citizenship behavior (OCB). As well as research conducted by Al-amri (2016) where compensation has a positive and significant effect on servant leadership has a positive and significant effect on organizational citizenship behavior (OCB).

\subsection{The Effect of Job Satisfaction Organizational Citizenship Behavior}

Based on the hypothesis testing in this study, the T-statistic value was 9,329 , the original sample value was 0.775 , and the $\mathrm{P}$-value was 0.000 . The T-statistic value is greater than the $\mathrm{T}$ table value of 1.96 , the original sample value shows a positive value, and the P-value is less than 0.05 . These results indicate that job satisfaction has a positive and significant effect on organizational citizenship behavior.

The results showed that the job satisfaction variable had a positive and significant effect on employees' level of organizational citizenship behavior as the object used in the study. Thus the job satisfaction felt by employees of PT Triple One Global affects employee organizational citizenship behavior. The satisfaction felt by employees of PT Triple One Global that comes from salaries, promotions, relationships with superiors or supervision and colleagues, or their work will increase organizational citizenship behavior. It is very important, and an indicator of job satisfaction is the relationship with superiors or supervision. Apart from that, the harmonious relationship between the employees of PT Triple One Global is also good. It certainly indicates that employee job satisfaction is good. Each unit carries out various activities to increase intimacy between employees. Service improvement activities carried out aim to improve employee service to stakeholders. Also, the training carried out has also been able to improve cooperation and communication between employees.

The results of this study support the research conducted by Oktavia and Laily (2017), which explains that job satisfaction has a positive and significant effect on organizational citizenship behavior (OCB). In the research results, $\mathrm{Ai}$ Rohayati (2014) shows that there is a positive and significant influence between job satisfaction and organizational citizenship behavior (OCB).

\subsection{Effect of Quality Of Work Life Organizational Citizenship Behavior}

Based on the hypothesis testing in this study, the T-statistic value was 4,783 , the original sample value was 0.401 , and the $\mathrm{P}$-value was 0.000 . The T-statistic value is greater than the Ttable value of 1.96 , the original sample value shows a positive value, and the $P$-value is less than 0.05 . These results indicate that the quality of work-life has a positive and significant effect on organizational citizenship behavior.

Quality of work-life (QWL) is to improve the organization's general work environment so that employees enjoy working because they have a pleasant experience interacting with one another. Organizational citizenship behavior (OCB) is behavior 
that exceeds the call of duty, which is not required by organizational members but is nonetheless important for organizational survival and effectiveness. It is explained that quality of work-life (QWL), apart from the employee's point of view, is also considered from an organizational perspective, which includes factors that measure organizational growth and effectiveness. This study explains that a high quality of worklife (QWL) is important for all organizations to attract and retain employees. Quality of work life is a comprehensive program aimed at increasing employee satisfaction and organizational citizenship behavior. Which, organizational citizenship behavior is a prosocial behavior that arises as a result of decent working conditions, which attracts employees to be able to actualize fully. Thus, this explanation reflects that the increase in quality of work-life (QWL) in a company will increase these employees' organizational citizenship behavior.

This study's results are following the results of research conducted by Uttunggadewi and Indrawati (2019), who found that quality of work-life has a positive and significant effect on organizational citizenship behavior. Ardilla, Hulmansyah, Huda (2018) stated that quality of work-life has a positive and significant effect on organizational citizenship behavior (OCB).

\section{Conclusion}

This study analyzes the variables related to servant leadership, job satisfaction, quality of work-life, and organizational citizenship behavior (OCB). The results of this study were obtained from research on employees of PT Triple One Global. From the results of the calculations in this study, the following conclusions can be drawn:

- Servant leadership has a significant positive effect on organizational citizenship behavior (OCB) in PT Triple One Global employees. It means that the stronger the servant leadership, the organizational citizenship behavior of employees will also increase.

- Job satisfaction has a significant positive effect on organizational citizenship behavior (OCB) on PT Triple One Global employees. It means that the higher the level of employees' job satisfaction, the increase in organizational citizenship behavior (OCB)

- Quality of work-life has a significant positive effect on organizational citizenship behavior (OCB) on PT Triple One Global employees. It reflects that the increasing quality of work-life (QWL) in a company will also increase these employees' organizational citizenship behavior.

Suggestions for the company should: (1) Leaders must provide peace to their subordinates in leading, such as providing solutions during morning coffee, being patient in overcoming every problem, and creating a comfortable working atmosphere; (2) The company should increase employee satisfaction, such as providing promotion for all employees who have good performance.; (3) The company must provide benefits following the performance that employees have generated by providing health insurance, pension money, education funds. If this is done, the employee's work quality will increase; (4) Companies must improve citizenship behavior for every employee, for example, by conducting regular outreach.

Suggestions for the next researcher, who will conduct research in the same field and use this thesis as a reference, it is necessary to re-examine it because it does not rule out that there are statements that are not appropriate because as a writer feel that there are still many shortcomings and limitations in completing the thesis.

\section{References}

[1] A.A. Anwar Prabu Mangkunegara. (2015). Manajemen Sumber Daya Manusia. Perusahaan Bandung: Remaja Rosdakarya

[2] Abdillah, Willy. "Jogiyanto. (2015)." Partial least square (PLS) alternatif structural equation modeling (SEM) dalam Penelitian Bisnis (2015): 225-255

[3] Ai Rohayati, (2014). Pengaruh Kepuasan Kerja Terhadap Organizational Citizenship Behavior: Studi Pada Yayasan Masyarakat Madani Indonesia. Smart- Study \& Manajement Recearch. vol 11. No. 1-2014. Pp. 20-38.

[4] Ardila, W., Hulmansyah, H., \& Huda, N. (2018). PENGARUH QUALITY OF WORK LIFE (QWL) DAN ORGANIZATIONAL CLIMATE TERHADAP KEPUASAN KERJA YANG BERIMPLIKASI PADA ORGANIZATIONAL CITIZENSHIP BEHAVIOUR (OCB) KARYAWAN DI POLITEKNIK LP3I JAKARTA. JURNAL LENTERA BISNIS, 7(1), 111. doi: 10.34127/jrlab.v7i1.221.

[5] Al-Amri, M. S. (2016). The Relationship between Servant Leadership and Organizational Citizenship Behavior: An Empirical Study on Saudi Insurance Companies. International Journal of Business and Management, 11(11), 264. doi: 10.5539/ijbm.v11n11p264

[6] Assiddiq, M. H. (2016). Gaya Kepemimpinan Dan Kualitas Kehidupan Kerja Terhadap Tingkat Turnover Karyawan (Studi Kasus Pada PT. Ebiz Cipta Solusi) (Doctoral dissertation, Universitas Widyatama)

[7] Barlin, N. A. (2016). Pengaruh Tipe Kepribadian, Kontrak Psikologis, Komitmen Organisasi, Motivasi dan Kepuasan Kerja Terhadap Organizational Citizenship Behavior (OCB) dan Kinerja Karyawan Di Rumah Sakit Paru Kabupaten Jember. Jurnal Relasi Stie Mandala Jember, 12(1), 366-373.

[8] Beck, C. D. (2014). Antecedents of Servant Leadership. Journal of Leadership \& Organizational Studies, 21(3), 299-314. doi: 10.1177/1548051814529993

[9] Bohlander, George., and Snell, Scott. (2010). Principless of Human Resource Management, 15th ed. Mason, $\mathrm{OH}$ : South Western - Cengage Learning

[10] Dessler, Gary. (2015). Manajemen Sumber Daya Manusia (Edisi 14). Jakarta: Salemba Empat

[11] Edison, Emron, Dr. Yohny Anwqar, dan Dr. Imas Komariyah (2016) Manajemen Sumber Daya Manusia, Strategi Dan Perubahan Dalam Rangka Meningkatkan Kinerja Pegawai Dan Organisasi, Bandung: Penerbit Alfabeta

[12] Fahruna, Y. (2016). Servant Leadership dan Kepuasan Kerja terhadap Kinerja Karyawan di Lembaga Keuangan Non Bank Pontianak. Jurnal Ekonomi Bisnis Dan Kewirausahaan, 5(3), 179. doi: 10.26418/jebik.v5i3.19080

[13] Ferdinand, (2014). Metode Penelitian Manajemen. (Edisi 5). Semarang: Badan Penerbit Universitas Diponegoro.

[14] George, M., \& Jones, R. (2012). Understanding and Managing Organizational Behaviour, 6th Edition, New Jersey: Prentice Hall.

[15] Ghozali, Imam. (2014). Structural Equation Modeling, Metode Alternatif dengan Partial Least Square (PLS). Edisi 4 Semarang: Badan Penerbit Universitas Diponegoro

[16] Hasibuan, Malayu S.P (2014). Manajemen Sumber Daya Manusia. Yogyakarta: PT. Bumi Aksara.

[17] Hair, Jr et.al. (2010). Multivariate Data Analysis (7th ed). United States: Person

[18] Hussein, A. S. (2015). Penelitian bisnis dan manajemen menggunakan Partial Least Squares (PLS) dengan SmartPLS 3.0. Universitas Brawijaya

[19] Kashani, Farideh H. (2012). A Review on Relationship between Quality of Work Life and Organizational Citizenship Behavior (Case Study: An Iranian Company). Journal of Basic and Applied Scientific Research. 2(9), 9523-9531

[20] Kurniawan Purnomo, A. (2018). Servant Leadership and Job Satisfaction as Ancedents Organizational Citizenship Behaviour on Educators. International Journal of Business and Management Invention(IJBMI), 7(3) Ver. II, 15-22.

[21] Luthans, F. (2011). Organizational Behavior: An Evidence-Based Approach (12th ed.). New York: The McGrow-Hill Companies.

[22] Marwansyah. (2014). Manajemen Sumber Daya Manusia. Bandung: Alfabeta

[23] Bayu Merdeka, I., \& Herminingsih, A. (2021). THE EFFECT OF COMPETENCY, ORGANIZATIONAL CITIZENSHIP BEHAVIOR 
AND WORK FAMILY CONFLICT ON EMPLOYEE PERFORMANCE AT THE SECRETARIAT DIRECTORATE GENERAL OF GUIDANCE ISLAMIC SOCIETY OF THE MINISTRY OF RELIGION OF THE REPUBLIC OF INDONESIA. Dinasti International Journal of Digital Business Management, 2(2), 345-359. doi: 10.31933/dijdbm.v2i2.777

[24] Mira, W. S., \& Margaretha, M. (2012). Pengaruh Servant Leadership Terhadap Komitmen Organisasi dan Organizarional Citizenship Behavior. Jurnal Manajemen, 11(2)

[25] Montolalu, Ricky dkk. (2016). Pengaruh Kepribadian, Orientasi Kerja, dan Penempatan Pegawai Terhadap Kinerja Pegawai Pada Dinas Kebudayaan Dan Pariwisata Provinsi Sulawesi Utara. Jurnal EMBA, 4(1)Maret.

[26] Newman, A., Schwarz, G., Cooper, B., \& Sendjaya, S. (2015). How Servant Leadership Influences Organizational Citizenship Behavior: The Roles of LMX, Empowerment, and Proactive Personality. Journal of Business Ethics, 145(1), 49-62. doi: 10.1007/s10551-015-2827-6

[27] Northouse, P. G. (2013). Kepemimpinan (6th ed.). California : Sage, inc.

[28] Nosratabadi, S., Khedry, H., \& Bahrami, P. (2015). A survei on the relationship of organizational commitment and Organizational Citizenship Behaviour. The SIJ Transactions on Industrial, Financial \& Business Management (IFBM), 3 (5), 58-66

[29] Oktavia, D. C., \& Laily, N. (2017). Pengaruh Kepuasan Kerja, Komitmen Organisasi dan Iklim Organisasi Terhadap Organizational Citizenship Behavior. Jurnal IImu \& Riset Manajemen, 6(10), 1-15

[30] Parvar, M. R. F., Allameh, S. M., \& Ansari, R. (2013). Effect of Quality of Work Life on Organizational Commitment by SEM (Case Study: OICO Company). International Journal of Academic Research in Business and Social Sciences, 3(10). doi: 10.6007/ijarbss/v3-i10/285

[31] Pio, R. J., \& Lengkong, F. D. J. (2020). The relationship between spiritual leadership to quality of work life and ethical behavior and its implication to increasing the organizational citizenship behavior. Journal of Management Development, 39(3), 293-305. doi: 10.1108/jmd-07-2018-0186

[32] Poli, W.I.M (2011). Kepemimpinan Stratejik; Pelajaran dari Yunani Kuno hingga Bangladesh. Makassar : Universitas Hasanuddin. Journal Of Economic And Business

[33] Putrana, Y., Azis F., \& Moh. M. W. (2016). Pengaruh Kepuasan Kerja dan Komitmen Organisasi Terhadap Organizational Citizenship Behavior Dalam Meningkatkan Kinerja Karyawan Pada PT. Gelora Persada Mediatama Semarang. Journal of Management, 2(2).

[34] Purnomo, A. K. (2019). Psychological capital dan kepuasan kerja sebagai anteseden organizational citizenship behavior pada tenaga pendidik. Jurnal Manajemen Maranatha, 19(1), 1-10. doi: $10.28932 / \mathrm{jmm} . v 19 i 1.1128$

[35] Robbins, Stephen P. \& Timoty A. Judge. (2015). Perilaku Organisasi. Jakarta: Penerbit Salemba Empat
[36] Sedarmayanti., \& Kuswanto, L. (2015). Pengaruh Leadership, Komitmen Organisasi dan Kepuasan Kerja Terhadap Organizational Citizenship Behavior. Jurnal IImu Administrasi, 7 (3)

[37] Setiawan, I., Asnawi, H. F., \& Sofyani, H. (2016). Apakah Ukuran, Profitabilitas, dan Praktik Manajemen Laba Memengaruhi Tingkat Pelaksanaan dan Pelaporan Islamic Social Reporting Pada Perbankan Syariah Di Indonesia? Jurnal Dinamika Akuntansi Dan Bisnis, 3(2), 65-76. doi: 10.24815/jdab.v3i2.5387

[38] Sugiyono, P. D. (2013). Metode Penelitian Manajemen. Bandung: Alfabeta, CV.

[39] Sugiyono, P.D. (2018). Metode Penelitian Bisnis: Pendekatan Kuantitatif, Kualitatif, Kombinasi, dan R\&D (Edisi ke-3 ed.), Bandung: Alfabeta, CV.

[40] Sunyoto, D. (2012). Teori, kuesioner, dan analisis data Sumber Daya Manusia (Praktik Penelitian). Yogyakarta: CAPS (Center for Academic Publishing Service).

[41] Sule, Erni Tisnawati dan Donni Juni Priansa. (2018). Kepemimpinan dan Perilaku Organisasi (Membangun Organisasi Unggul di Era Perubahan). Bandung: Refika Aditama.

[42] Sutrisno, E. (2014). Manajemen Sumber Daya Manusia. Jakarta: Kencana Prenada Media Group

[43] Titisari, Purnamie. (2014). Peranan Organizational Citizenship Behavior (OCB)Dalam Meningkatkan Kinerja Karyawan. Jakarta: Mitra Wacana Media.

[44] Totalia, S. A., \& Hindrayani, A. (2013). SPSS \& DEA "Implementasi pada Bidang Pendidikan dan Ekonomi".

[45] Uttunggadewi, Indrawati (2019). Hubungan Antara Kualitas Kehidupan Kerja dengan Organizational Citizenship Behavior (OCB) pada Karyawan bagian Customer Service PT. Garuda Indonesia. Jurnal Empati, 8(1) 144-150

[46] Vondey, M. (2010). The Relationships among Servant Leadership, Organizational Citizenship Behavior, Person-Organization Fit, and Organizational Identification. International Journal of Leadership Studies. 6 (1), 3-27

[47] Wibowo, (2017). Quality of Work Life: A Review and Synthensis. Jurnal Bisnis Teori dan Impelementasi, 8 (1), 84-96

[48] Harwiki, W. (2016). The Impact of Servant Leadership on Organization Culture, Organizational Commitment, Organizational Citizenship Behaviour (OCB) and Employee Performance in Women Cooperatives. Procedia - Social and Behavioral Sciences, 219, 283-290. doi: 10.1016/j.sbspro.2016.04.032

[49] Yulk, Gary (2015), Kepemimpinan Dalam Organisasi (Edisi 7). Jakarta Penerbit Indeks 